\title{
IAMJ
}

INTERNATIONAL

AYURVEDIC

MEDICAL JOURNAL

Research Article

ISSN: 2320-5091

Impact Factor: 6.719

\section{AN OPEN CLINICAL STUDY OF UTKLESHANA, DOSHAHARA AND SAMSHAMANA YOG-BASTI IN JANU-SANDHIGATAVATA: A PILOT STUDY}

\author{
Lodha Sheetal $\mathbf{G}^{\mathbf{1}}$, Karade Ruchika $\mathrm{S}^{\mathbf{2}}$ \\ ${ }^{1}$ Assistant Professor, ${ }^{2}$ PG scholar, Dept. of Panchakarma, R.A. Poddar Medical Ayu College, Mumbai, \\ Maharashtra, India
}

Corresponding Author: vd.sheetal4u@rediffmail.com

https://doi.org/10.46607/iamj.1309012021

(Published online: January 2021)

Open Access

(C) International Ayurvedic Medical Journal, India 2021

Article Received: 12/10/2020 - Peer Reviewed: 04/01/2021 - Accepted for Publication: 16/01/2021

D) Check for updates

\begin{abstract}
Background: Sandhigatvata is described under Vatavyadhi in Brihatrayi. It resembles with Osteoarthritis. Basti is supreme therapy for Vatavyadhi and has entity to entice all doshas. In order to treat a disease, first to break down the dosha-dushya samurchhana i.e. etiopathogenesis. Acharya Sushruta has made a set of packaged basti known as Utkleshana, Doshahara and Samshamana in sequential manner which works on the anutklisht dosha, bring them in kosta and expel out. Aim: To evaluate the effect of Utkleshana, Doshahara and Samshamana basti in Janu-Sandhigatvata. Methods and materials: In present randomised clinical pilot study, 10 patients of JanuSandhigatvata were given Utkleshana, Doshahara and Samshamana basti in Yoga basti pattern where these basti were given as Niruha and Tila taila was used for Anuvasana basti in between. Subjective assessment of pain by visual analog scale and Shotha (swelling), Vatapurnadrutisparsha (crepitus) were graded according to their severity. The angle of flexion and extension of knee joint was recorded by goniometer. Results: Significant results were found in all cardinal symptoms pain, Shotha (swelling), Vatapurnadrutisparsha (crepitus) and angle of flexion and extension of knee joint. Conclusion: Utkleshana, Doshahara and Samshamana basti in Yoga basti pattern was significant in subjective and objective symptoms of Janu-Sandhigatavata.
\end{abstract}

Keywords: Utkleshana, Doshahara, Samshamana, Basti, Janu-Sandhigatvata, Panchakarma. 


\section{INTRODUCTION}

The importance of Panchakarma in Ayurveda is brought out by the fact that it is applicable to all cases covering as a wide range of preventive, curative and promotive conditions. It is postulated that the vitiated Doshas and Malas of the body need to be eliminated before any specific measures is taken to cure the disease because no one therapy works well if Shodhana measures are not taken beforehand.

Basti Chikitsa is one of supreme therapy for the elimination of vitiated Doshas and hence called as Ardha Chikitsa $^{l}$. In the present clinical study with the reference of Acharya Sushruta, the scientific application of Utkleshana, Doshahara and Samshamana Basti ${ }^{2}$ has an approach towards the Dhatugat ${ }^{3}$ Doshharana in all aspects of disease. In the Shodhana therapy the Doshas which are situated at Dhatugat level and are in Anutklisht stage, are more difficult to expel out. In this condition one needs the kind of Basti which works on the Anutklisht Dosha, bring them in Kosta and expel out. Acharya Sushruta has made a set of packaged Basti known as Utkleshana, Doshahara and Samshamana in sequential manner ${ }^{4}$. No doubt by Abhyantar Snehana, Swedana the tremendous Utkleshana of Doshas and bring back them to Kosta is achieved but as comparing to the prior one has more time consuming, non-palatable and in case of emergency it is not so easy. In case of Basti it overcomes of all problems of Abhyantar Snehana and Swedana.

Osteoarthritis (OA) is the second most common rheumatologic problem in India and has prevalence rate of $22-39 \% .^{5}$ It is characterized primarily by articular cartilage degeneration and a secondary periarticular bone response. ${ }^{6}$, World-wide prevalence rate of OA is $20 \%$ for men, $41 \%$ for women, and it causes pain or dysfunction in $20 \%$ of elderly respectively ${ }^{7}$ Relieving pain, stiffness, and improving physical functions are important goals of present day therapy. Although OA itself is not a life-threatening disease, quality of life can significantly deteriorate with pain and loss of mobility causing dependence and disability ${ }^{8}$. In Ayurve$\mathrm{da}$, the disease Sandhigatvata resembles with OA, which described under Vatavyadhi. ${ }^{9}$
In present clinical study, the Utkleshana drugs like Erandbeeja, Madhuka, Pippali etc, doshahara drugs like Shatahwa, Madhuka, Madanphala, Gomutra, Kanji etc and Samshamana drugs like Priyangu, Musta, Rasanjana, Goksheera etc are schematically arranged in the pattern of Yoga Basti i.e. within total three Niruha Basti, first one is Utkleshana, second is Doshahara and last one is Samshamana Basti. The remaining five are Anuvasan basti with Tila Taila.

Aim: To evaluate the effect and consequences of Utkleshana Basti, Doshahara Basti and Samshamana Basti in Janu-Sandhigatavata.

\section{Objectives:}

To evaluate the effect of Utkleshana, Doshahara and Samshamana Basti.

1. on Sandhishoola by VAS scale

2. on movement of knee joint i.e. flexion and extension by Goniometer.

3. on Sandhishotha

4. on Vatapurnadruti sparsha.

\section{Materials and Method:}

This pilot study was conducted on 10 patients with classical sign and symptoms of Janu-Sandhigatvata by adopting proper assessment criteria. All patients were treated by taken a consent with Tila Taila Anuvasan and Utkleshan, Doshahara and Samshaman Basti as Niruha in Yoga Basti manner.

Source of Data: for this study the patients were selected from the IPD and OPD of Panchakarma department of R. A. Poddar Medical Ayurveda college and hospital and a case proforma was prepared by incorporating the signs and symptoms of Sandhigatvata.

Study Design: The study design was randomised. Patients were selected according to the inclusion and exclusion criteria.

\section{Inclusion Criteria}

1. Age group between 30 to 60 years both male and female.

2. Patients having signs and symptoms of Sandhigatvata as per classical text for

minimum 3 months.

3. Patients fit for Basti chikitsa.

4. Patients without any anatomical deformity. 


\section{Exclusion Criteria}

1. Patients contraindicated for Basti chikitsa.

2. Patient suffering from rheumatoid arthritis or another major joint disease.
3. Pregnant women, lactating mothers and during menstrual cycle.

4. Fracture of femur, tibia and dislocation of knee joint.

Table 1: Treatment modality of Utkleshana, Doshahara and Samshamana Basti in Janu-Sandhigatvata.

\begin{tabular}{|c|c|c|c|c|}
\hline No. & Procedure & Drug & Dose & Duration \\
\hline 1. & $\begin{array}{l}\text { Poorva karma } \\
\text { Sarvangaabhyanga } \\
\text { Bashpaswed }\end{array}$ & $\begin{array}{l}\text { Moorchit Tila Taila } \\
\text { Dashmooladi Dravyas }\end{array}$ & Q. S. & $\begin{array}{l}20-30 \text { mins } \\
10-15 \text { mins }\end{array}$ \\
\hline 2. & $\begin{array}{l}\text { Pradhana karma } \\
\text { (Yoga Basti) } \\
\text { Anuvasana basti } \\
\text { Niruhabasti } \\
\text { A) Utkleshana basti dravya } \\
\text { Erandabija, Madhuka, } \\
\text { Pippali, Saindhav lavana, } \\
\text { Vacha, and Hapushakalka }\end{array}$ & $\begin{array}{l}\text { Tila Taila } \\
\text { Saindhavlavana } \\
\text { Madhu } \\
\text { Tila taila } \\
\text { Utkleshana basti kalka dravya } \\
\text { Utkleshana basti kwatha dravya } \\
\text { Total approx.. }\end{array}$ & $\begin{array}{l}120 \mathrm{ml} \\
10 \mathrm{gm} \\
40 \mathrm{gm} \\
100 \mathrm{ml} \\
50 \mathrm{gm} \\
500-600 \mathrm{ml}\end{array}$ & $\begin{array}{l}1^{\text {st }}, 3^{\text {rd }}, 5^{\text {th }}, 7^{\text {th }}, \\
8^{\text {th }} \text { day } \\
2^{\text {nd }} \text { day }\end{array}$ \\
\hline & $\begin{array}{l}\text { B) Doshahara basti dravya } \\
\text { Shatahwa,Madhuka,Kutaja bee- } \\
\text { ja,Madanphala,Kaanjika } \\
\text { and Gomutra }\end{array}$ & $\begin{array}{l}\text { Saindhavlavana } \\
\text { Madhu } \\
\text { Tila Taila } \\
\text { Doshahara basti kalka dravya } \\
\text { Doshahara basti kwatha dravya } \\
\text { Total approx. } \\
\text { Saindhav lavana } \\
\text { Madhu } \\
\text { Tila taila } \\
\text { Samshamana basti kalka dravya } \\
\text { Samshamana basti kwatha dravya } \\
\text { Total approx.. }\end{array}$ & $\begin{array}{l}10 \mathrm{gm} \\
40 \mathrm{gm} \\
100 \mathrm{ml} \\
50 \mathrm{gm} \\
500-600 \mathrm{ml} \\
700-800 \mathrm{ml} \\
10 \mathrm{gm} \\
40 \mathrm{gm} \\
100 \mathrm{ml} \\
50 \mathrm{gm} \\
500-600 \mathrm{ml} \\
700-800 \mathrm{ml}\end{array}$ & $4^{\text {th }}$ day \\
\hline & Paschath karma & $\begin{array}{l}\text { Lift the legs, padding to the buttocks, } \\
\text { anticlockwise massage to abdomen etc. }\end{array}$ & & 8-10 mins. \\
\hline
\end{tabular}

Table 2: Drug review of Utkleshana, Doshahara and Samshamana Basti

\begin{tabular}{|l|l|l|l|l|l|l|l|}
\hline Sr. No. & Drug & Latin name & Ras & Virya & Vipaka & Guna & Doshaghnata \\
\hline 1. & Eranda $^{10}$ & $\begin{array}{l}\text { Ricinus com- } \\
\text { munis }\end{array}$ & $\begin{array}{l}\text { Madhur } \\
\text { Katu, } \\
\text { Kashay }\end{array}$ & Ushna & Madhur & $\begin{array}{l}\text { Snigdha } \\
\text { Tikshna } \\
\text { Sukshma }\end{array}$ & $\begin{array}{l}\text { Kaphavata } \\
\text { shamak }\end{array}$ \\
\hline 2. & Madhuk $^{11}$ & $\begin{array}{l}\text { Glycyrrhiza } \\
\text { glabra }\end{array}$ & Madhur & Shit & Madhur & $\begin{array}{l}\text { Guru } \\
\text { Snigdha }\end{array}$ & Vata-Pittashamak \\
\hline 3. & Pippali $^{12}$ & Piper longum & Katu & $\begin{array}{l}\text { Anushna } \\
\text { shit }\end{array}$ & Madhur & $\begin{array}{l}\text { Laghu, } \\
\text { Snigdha, } \\
\text { Tikshna }\end{array}$ & Kaphavatavardhak \\
\hline
\end{tabular}


Lodha Sheetal G \& Karade Ruchika S: An Open Clinical Study Of Vtkleshana, Doshahara And Samshamana Yog-Basti In JanuSandhigatavata: A Pilot Study

\begin{tabular}{|c|c|c|c|c|c|c|c|}
\hline 4. & Vacha ${ }^{13}$ & Acorus calamus & $\begin{array}{l}\text { Katu, } \\
\text { Tikta }\end{array}$ & Ushna & Katu & $\begin{array}{l}\text { Laghu } \\
\text { Tikshna }\end{array}$ & $\begin{array}{l}\text { Kaphavatashamak } \\
\text { pittavardhak }\end{array}$ \\
\hline 5. & Hapusha ${ }^{14}$ & $\begin{array}{l}\text { Juniperus } \\
\text { communis }\end{array}$ & $\begin{array}{l}\text { Katu } \\
\text { Tikta }\end{array}$ & Ushna & Katu & $\begin{array}{l}\text { Laghu, } \\
\text { Ruksha, } \\
\text { Tikshna }\end{array}$ & Kaphavatashamak \\
\hline 6. & Shatavha 15 & Anethum sowa & Katu, Tikta & Ushna & Katu & $\begin{array}{l}\text { Laghu, } \\
\text { Ruksha, } \\
\text { Tikshna }\end{array}$ & $\begin{array}{l}\text { Kaphavata } \\
\text { shamak }\end{array}$ \\
\hline 7. & $\begin{array}{l}\text { Kutaja } \\
\text { Beej }^{16}\end{array}$ & & Katu & Shit & Katu & & Tridoshaghna \\
\hline 8. & $\begin{array}{l}\text { Madan- } \\
\text { Phalal }^{17}\end{array}$ & Randia spinosa & $\begin{array}{l}\text { Kashay, } \\
\text { Madhur } \\
\text { Tikta, Katu }\end{array}$ & Ushna & Katu & $\begin{array}{l}\text { Laghu, } \\
\text { Ruksha }\end{array}$ & Kaphapittashodhak \\
\hline 9. & Priyangu ${ }^{18}$ & $\begin{array}{l}\text { Callicarpa } \\
\text { macrophylla }\end{array}$ & $\begin{array}{l}\text { Tikta } \\
\text { Madhur } \\
\text { kashay }\end{array}$ & Shit & Katu & $\begin{array}{l}\text { Guru } \\
\text { Ruksha }\end{array}$ & Vatpitrtashamak \\
\hline 10 & Musta $^{19}$ & $\begin{array}{l}\text { Cyperus rotun- } \\
\text { dus }\end{array}$ & $\begin{array}{l}\text { Tikta } \\
\text { Katu } \\
\text { Kashay }\end{array}$ & Shit & Katu & $\begin{array}{l}\text { Laghu } \\
\text { Ruksha }\end{array}$ & Kaphapittashamak \\
\hline 11 & Rasanjan $^{20}$ & Berberis aristata & Katu & Ushna & Katu & $\begin{array}{l}\text { Laghu } \\
\text { Ruksha }\end{array}$ & Kaphanut \\
\hline 12 & Saindhav ${ }^{21}$ & Rock salt & Lawan & Shit & & $\begin{array}{l}\text { Laghu, Snigdh, } \\
\text { Sukshma }\end{array}$ & Tridoshaghna \\
\hline 13 & Kanji $^{22}$ & & & Ushna & & Laghu & Vatakaphapaham \\
\hline 14 & Kshir ${ }^{23}$ & Cow-Milk & Madhur & Shit & Madhur & $\begin{array}{l}\text { Guru } \\
\text { Snigdha }\end{array}$ & Vatpittaastranashak \\
\hline 15 & Gomutra $^{24}$ & Cow-urine & $\begin{array}{ll}\text { Katu } & \text { tikta } \\
\text { Kashay } & \end{array}$ & Ushna & Katu & $\begin{array}{l}\text { Teekshna, ushna, } \\
\text { laghu }\end{array}$ & Vatashamak \\
\hline
\end{tabular}

\section{Assessment Criteria}

Subjective parameters- Shula (Pain) by $10 \mathrm{~cm}$ Visual Analog Scale, Graha, Shotha, Vatapurnadrutisparsha by gradation method.

\section{Objective parameters-}

Angle of flexion and extension of knee joint by Goniometer.

Chart showing the grading of parameters

Table 3: Gradation of range of motion of knee joints

\begin{tabular}{|l|l|}
\hline Normal joint motion & Grade 0 \\
\hline About $25-49 \%$ loss of motion & Grade 1 \\
\hline About $50 \%$ loss of motion & Grade 2 \\
\hline About $75 \%$ loss of motion & Grade 3 \\
\hline $100 \%$ loss of motion & Grade 4 \\
\hline
\end{tabular}

Table 4: Gradation of crepitus in knee joints i.e. vatapurnadrutisparsha

\begin{tabular}{|l|l|}
\hline No crepitus & Grade 0 \\
\hline Fine on palpation & Grade 1 \\
\hline Low audible coarse, without palpation & Grade 2 \\
\hline Highly audible & Grade 3
\end{tabular}


Table 5: Gradation of swelling of Knee joints i.e Shotha

\begin{tabular}{|l|l|}
\hline No swelling & Grade 0 \\
\hline $\begin{array}{l}\text { Joint swelling which may not be apparent on casual inspection, but difficult to } \\
\text { recognise on casual observation }\end{array}$ & Grade 1 \\
\hline Joint swelling obvious even on casual observation & Grade 2 \\
\hline Markedly abnormal swelling & Grade 3 \\
\hline Joint swelling to a maximally abnormal degree & Grade 4 \\
\hline
\end{tabular}

\section{Observations:}

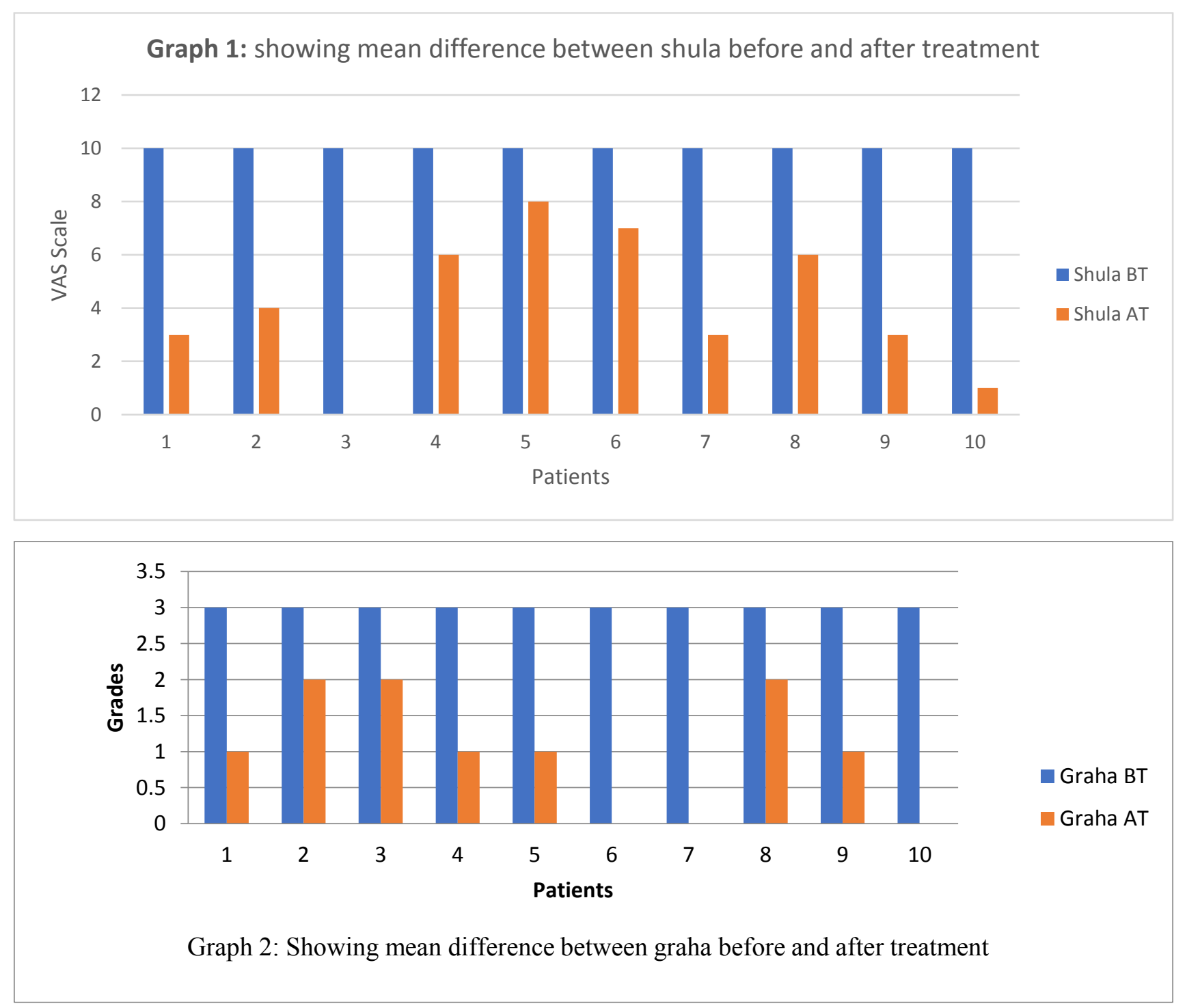




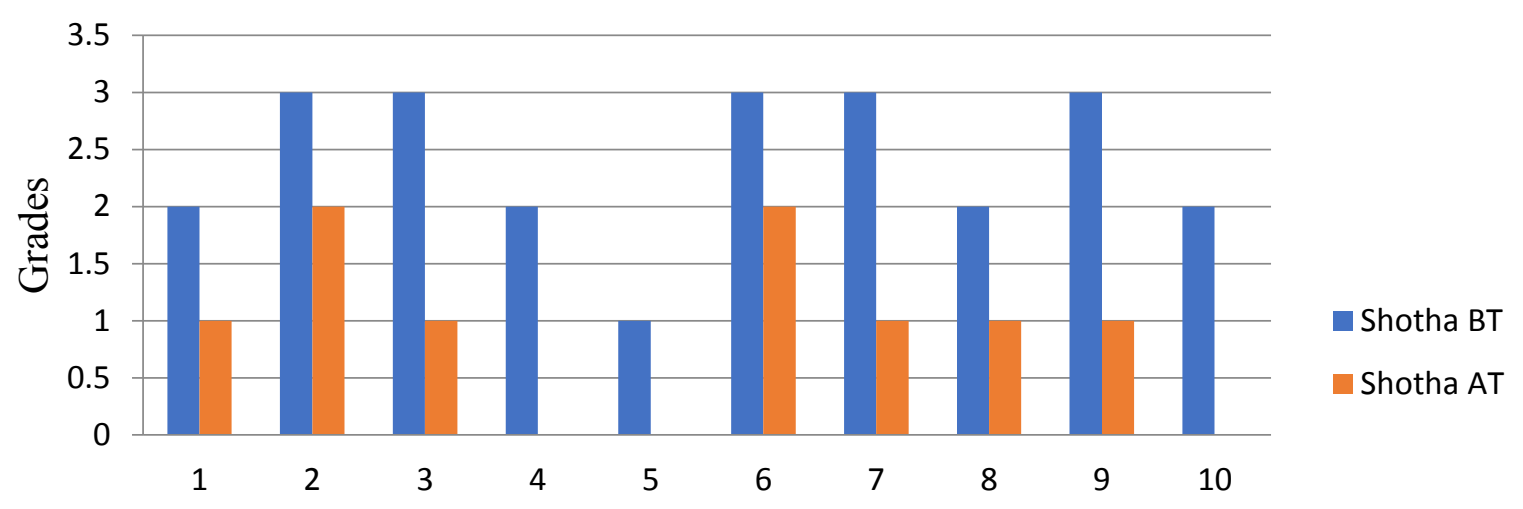

Graph 3: Showing mean difference of shotha before and after treatment

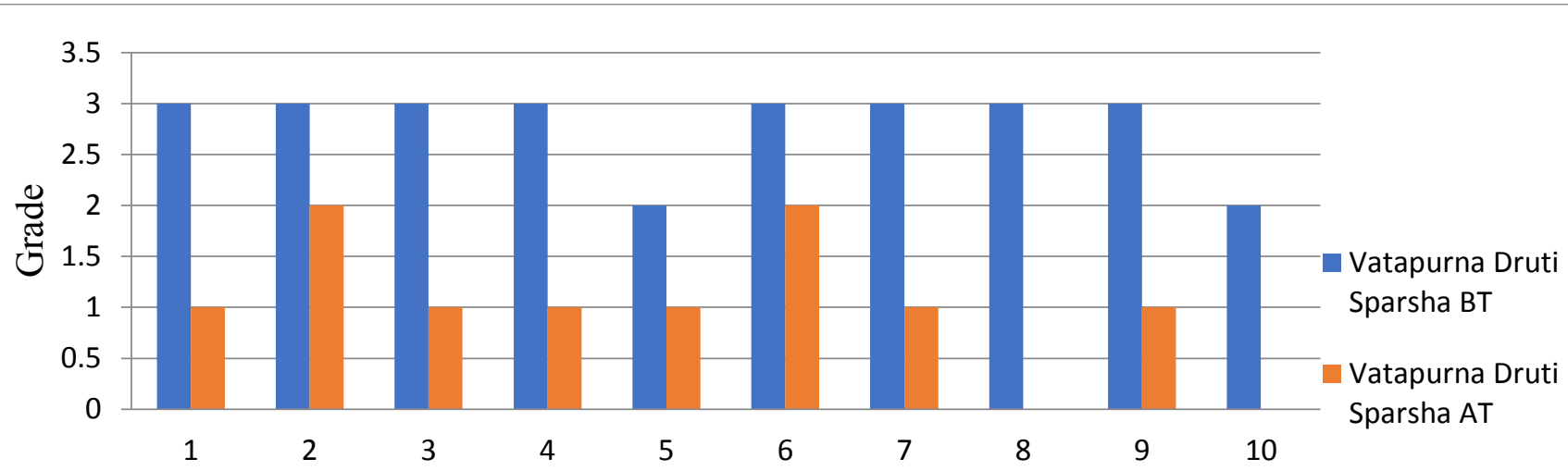

Graph 4: Showing mean difference of vatpurnadrutisparsha before and after treatment

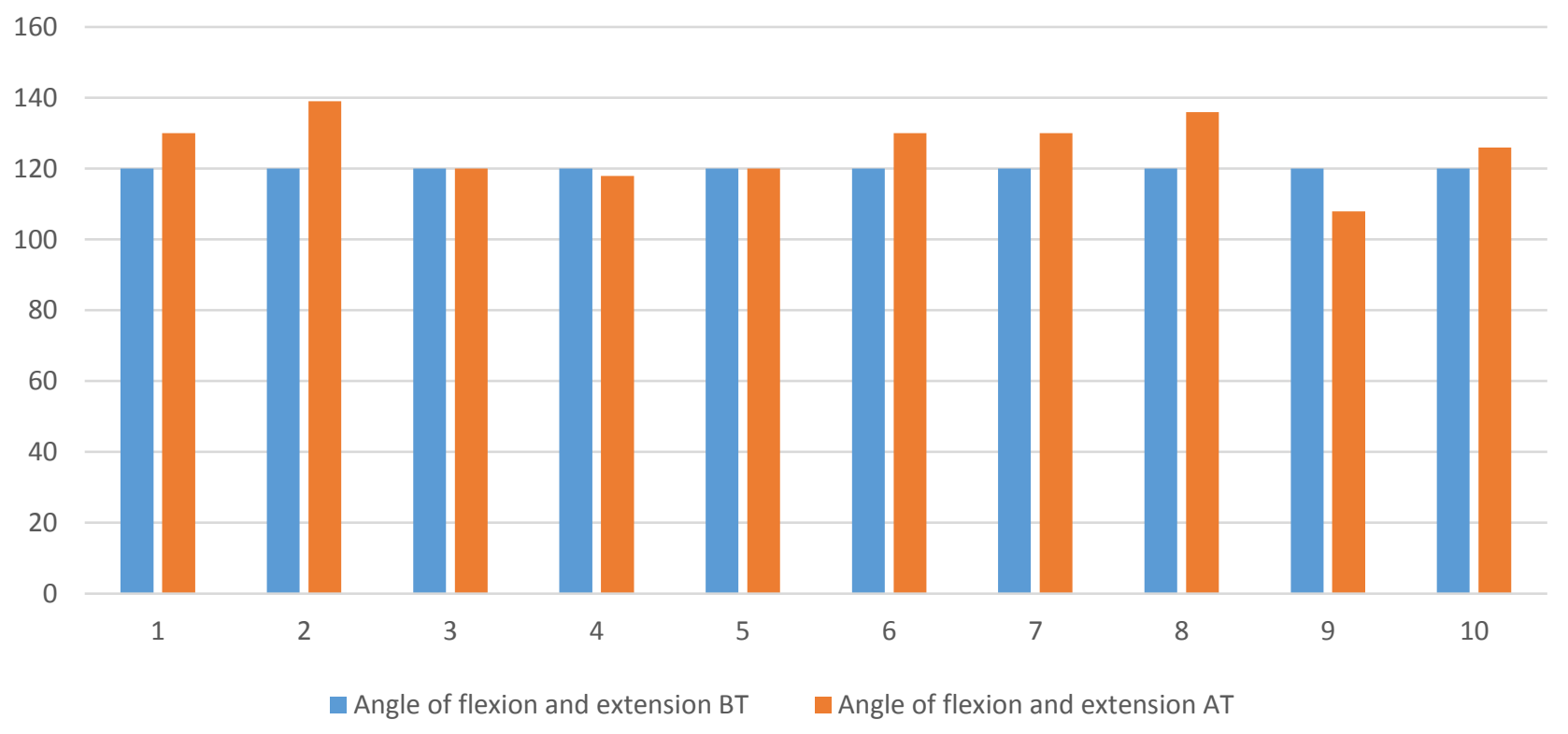




\section{RESULTS AND DISCUSSION}

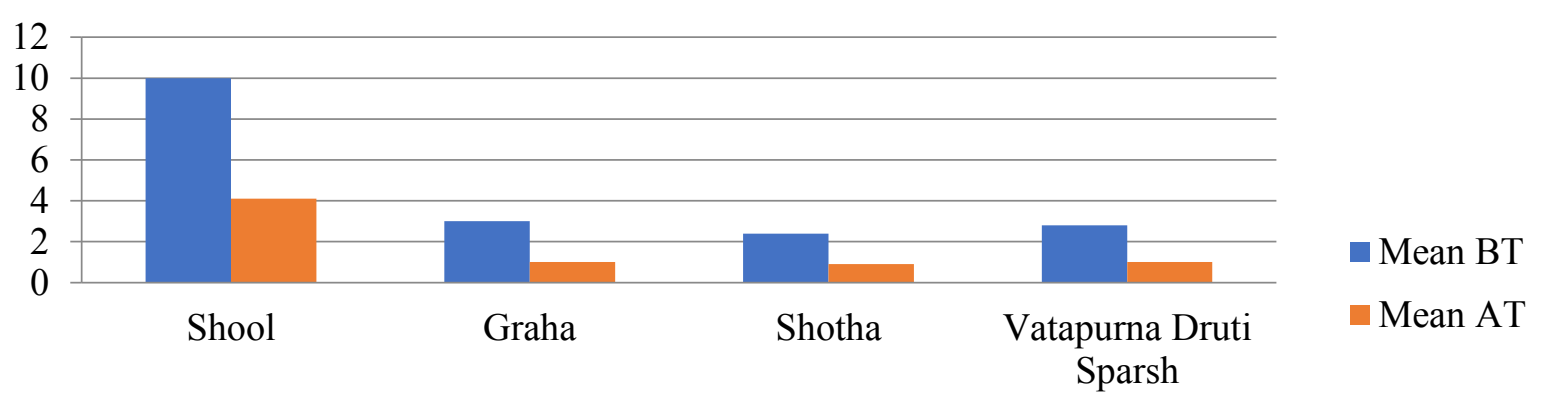

Graph 5: Mean Difference Of Symptoms Before \& After Treatment

- Effect on Sandhishula - Relief in Sandhishula was observed $70 \%$ among the patients.

- Effect on Graha - In the patients, significant results were recorded in Graha of the joints is $60 \%$.

- Effect on Sandhishotha - In the patients highly significant improvement was recorded in inflammation, showed $60 \%$ relief.

- Effect on Vatpurnadrutisparsha - $70 \%$ Results were recorded in Vatpurnadrutisparsha of the joints.

- Effect on angle of flexion and extension- $60 \%$ results were recorded in angle of flexion and extension of the knee joints.

Sandhigatavata is a disorder dominated by pain affecting the Sandhi (joint). It is caused by morbid Vata Dosha. Kapha Dosha may also be involved in the clinical presentation. The vitiated Dosha affects the Mamsa, Asthi and Snayu. Pain and crepitus are mainly due to Vata Dosha and above data proves that Utkleshanadi Basti controls Vata Dosha and relieves these symptoms.

Brief mode of action of Utkleshana, Doshahara and Samshamana Basti- The Utkleshana Basti having the properties of Teekshna, Snigdha, Laghu, Sukshma, Picchila and part of Guru are having similar properties of Kapha and Ama by that they spread all over the body with the help of Apana, Samana and Vyanavayu. Their increase in the quantitative consistency of Doshotklesha, and bring back to the Kosta i.e. Pakwashaya and expel the unwanted Mala by keeping Utkleshita Dosha in their own site followed by admin- istration of Doshaharabasti causes the elimination of Dhatugatadosha and Utklishtadosha from its root level by the virtue of its Ushna, Tikshna, Vyavayi, Vikasi and Strotogamigunas after that at lastly for the purpose of pacification of Leenadosha, to prevent the further formation of Ama and restoration of normal health is achieved with the help administration of Samshamana Basti by virtue of their Madhura, Tikta Rasa with Snigdha, Laghu and Rooksha Gunas these three packaged Basti have mainly acts by virtue of their presence of drug effect as well as the procedure effect.

Basti is one of the supreme lines of treatment among all panchakarmas because of its multi- dimensional actions in multi corners. Among all three Basti i.e. Utkleshana, Doshahara and Samshamana, Utkleshana has fine effect on Doshotkleshana due to presence of Erandbeeja, Pippali, Hapusha etc are most Utkleshana drugs without irritating to the patient.

The Doshahara Basti has supreme eradicative method of already Utklishtadosha as comparing to other Teekshna Basti mentioned in classics. Even after giving $800 \mathrm{ml}$ to the patients it not at all creates the side effects, because of presence of Madanaphala and Kutaja. The Samshamana Basti has best choice immediately after Shodhana because as it digests the Linadoshas as well as prevents the further formation of Sama Dosha also it prevents the Vataprakopa if aroused by Doshahara or any Teekshna Basti and restore the normal health in all ways, due to active ingredient like Goksheera, Priyangu, Rasanjana, 
Madhuka etc. All the Basti are set under a packaged form having action like preventive, curative and promotive of health in a step ladder pattern. This packaged form Basti if we used under the light of Kala Basti will have significant results as compared to $\mathrm{YO}$ ga Basti in future.

\section{CONCLUSION}

Utkleshana, Doshahara and Samshamana Basti administered as Niruha in Yog Basti manner is effective in reducing pain, crepitus, decreased range of motion of knee joints and swelling of Janu-Sandhigatavata.

\section{REFERENCES}

1. Agnivesha, Charaka, Dridhabala, Charak Samhita, Siddhi Sthana, Kalpanasiddhi Adhyay, 1/39-40, edited by Jadhavji Trikamaji Acharya, Reprint ed. Chaukhambha Surbharati Publication, Varanasi, 2018; 683.

2. Sushruta, Sushruta Samhita, with the Nibandhasangraha Commentary by Dalhanaacharya and the Nyayachandrikakhya Panjika of Sri Gayadasacharya, Chikitsasthana, Niruhachikitsit Adhyay, 38/93-95, edited by Vaidya Yadavji Trikamji Acharya. Chaukhamba Surbharati prakashan, Reprint ed 2018; 547.

3. Sushruta, Sushruta Samhita, with the Nibandhasangraha Commentary by Dalhanaacharya and the Nyayachandrikakhya Panjika of Sri Gayadas Acharya, Chikitsasthana, Niruhachikitsit adhyay, 38/93-95, edited by Vaidya Yadavji Trikamji Acharya. Chaukhamba Surbharati prakashan, Reprint ed 2018; 547.

4. Sushruta, Sushruta Samhita, with the Nibandhasangraha Commentary by Dalhanaacharya and the Nyayachandrikakhya Panjika of Sri Gayadasacharya, Chikitsasthana, Niruhachikitsit adhyay, 38/92, edited by Vaidya Yadavji Trikamji Acharya. Chaukhamba Surbharati prakashan, Reprint ed 2018; 546.

5. Chopra A, Patil J, Billempelly V, Relwani J, Tandle HS. WHO-ILAR COPCORD Study. WHO International League of Associations from Rheumatology Community Oriented Program from Control of Rheumatic disease. Prevalence of rheumatic diseases in a rural population in western India: A WHO-ILAR COPCORD Study. J Assoc Physicians India 200; 49:240-6.

6. Felson DT. An update on the pathogenesis and epidemiology of osteoarthritis. Radiol Clin North Am 2004; 42:1-9

7. Lawrence JS, Bremner JM, Bier F. Osteo-arthrosis. Prevalence in the population and relationship between symptoms and x-ray changes. Ann Rheum Dis 1966; 25:1-24.

8. Patrick DL, Deyo RA. Generic and disease-specific measures in assessing health status and quality of life. Med Care 1989;27: S217-32.

9. Agnivesha, Charaka, Dridhabala, Charak Samhita, Chikitsa Sthana, Vatvyadhichikitsa Adhyay, 28/37, edited by Jadhavji Trikamaji Acharya, Reprint ed. Chaukhambha Surbharati Publication, Varanasi, 2018; 618.

10. Bhavmishra, Bhavprakash Nighantu, with commentary of Krushnachandra Chunekar, edited by Gangasahay Pandey, Haritakyadi varga, verse 64-65, Choukhamba Bharati Academy, Varanasi, Reprint 2020; 286.

11. Bhavmishra, Bhavprakash Nighantu, with commentary of Krushnachandra Chunekar, edited by Gangasahay Pandey, Haritakyadi varga, verse 145-146, Choukhamba Bharati Academy, Varanasi, Reprint 2020; 62.

12. Bhavmishra, Bhavprakash Nighantu, with commentary of Krushnachandra Chunekar, edited by Gangasahay Pandey, Haritakyadi varga, verse 53-57, Choukhamba Bharati Academy, Varanasi, Reprint 2020; 15.

13. Bhavmishra, Bhavprakash Nighantu, with commentary of Krushnachandra Chunekar, edited by Gangasahay Pandey, Haritakyadi varga, verse102-103, Choukhamba Bharati Academy, Varanasi, Reprint 2020; 42.

14. Bhavmishra, Bhavprakash Nighantu, with commentary of Krushnachandra Chunekar, edited by Gangasahay Pandey, Haritakyadi varga, verse 110, Choukhamba Bharati Academy, Varanasi, Reprint 2020; 48.

15. Bhavmishra, Bhavprakash Nighantu, with commentary of Krushnachandra Chunekar, edited by Gangasahay Pandey, Haritakyadi Varga, verse 89-92, Choukhamba Bharati Academy, Varanasi, Reprint 2020; 34.

16. Bhavmishra, Bhavprakash Nighantu, with commentary of Krushnachandra Chunekar, edited by Gangasahay Pandey, Haritakyadi Varga, verse 158-159, Choukhamba Bharati Academy, Varanasi, Reprint 2020; 73.

17. Bhavmishra, Bhavprakash Nighantu, with commentary of Krushnachandra Chunekar, edited by Gangasahay Pandey, Haritakyadi varga, verse 160-161, Choukhamba Bharati Academy, Varanasi, Reprint 2020; 74.

18. Bhavmishra, Bhavprakash Nighantu, with commentary of Krushnachandra Chunekar, edited by Gangasahay Pandey, Karpuradi Varga, verse 101-103, Choukhamba Bharati Academy, Varanasi, Reprint 2020; 237.

19. Bhavmishra, Bhavprakash Nighantu, with commentary of Krushnachandra Chunekar, edited by Gangasahay 
Pandey, Karpuradi Varga, verse 92-94, Choukhamba Bharati Academy, Varanasi, Reprint 2020; 232.

20. Bhavmishra, Bhavprakash Nighantu, with commentary of Krushnachandra Chunekar, edited by Gangasahay

Pandey, Haritakyadi Varga, verse 203-205, Choukhamba Bharati Academy, Varanasi, Reprint $2020 ; 118$.

21. Bhavmishra, Bhavprakash Nighantu, with commentary of Krushnachandra Chunekar, edited by Gangasahay Pandey, Haritakyadi Varga, verse 241, Choukhamba Bharati Academy, Varanasi, Reprint 2020; 149.

22. Bhavmishra, Bhavprakash Nighantu, with commentary of Krushnachandra Chunekar, edited by Gangasahay Pandey, Sandhan Varga, verse 1-3, Choukhamba Bharati Academy, Varanasi, Reprint 2020; 767.

23. Bhavmishra, Bhavprakash Nighantu, with commentary of Krushnachandra Chunekar, edited by Gangasahay Pandey, Dugdh Varga, verse 7-8, Choukhamba Bharati Academy, Varanasi, Reprint 2020; 742.

24. Bhavmishra, Bhavprakash Nighantu, with commentary of Krushnachandra Chunekar, edited by Gangasahay Pandey, Mutra Varga, verse 1-6, Choukhamba Bharati Academy, Varanasi, Reprint 2020; 761.

\section{Source of Support: Nil}

\section{Conflict of Interest: None Declared}

How to cite this URL: Lodha Sheetal G \& Karade Ruchika S: An Open Clinical Study Of Utkleshana, Doshahara And Samshamana Yog-Basti In Janu-Sandhigatavata: A Pilot Study. International Ayurvedic Medical Journal \{online\} 2021 \{cited January, 2021\} Available from: http://www.iamj.in/posts/images/upload/100_108.pdf 